\title{
Just Looking
}

\author{
John Walsh \\ Drawings by Malcolm Walker
}

There's nothing like editing an architecture magazine to turn you into a lookist. I should know - for almost a decade I edited Architecture New Zealand, and by the end of my tenure I was a chronic breaker of all those age-old folk commandments anathematising superficiality. (Every magazine editor not only believes you can indeed judge a book by its cover, but also has an almost mystical belief in the charisma of the cover.) I spent a good part of my working day judging buildings by their appearances. Or, more accurately, by photographs of their façades.

Seated at my desk, my relationship to many buildings was necessarily distant. Twice removed from reality, I was connected to architecture through photography, a linkage that in genealogy might be represented by the broken line of illegitimacy. It's not that all photographers are bastards, but, with their filters and framings and post-shooting fiddlings, they're dodgy characters all, spin-doctors with lenses. Every photograph of a building should come with a caveat: after Magritte, it could read, "This is not a building."

Of course, photographers, with their acute commercial instincts, won't supply what's not demanded. Editors are full partners in the exteriority business, as are the architects whose work they cover. Architectural publishing is, literally, show business. When presenting projects, editors, with the encouragement of architects and their clients, customarily exercise a preferential option for beauty over truth, certainly over the whole truth.

Architectural publishing is a synergy of two different but highly compatible impulses. On the one hand, an editor's desire and an art director's compulsion to produce an attractive publication preclude selection of any pictures that might stink up the title. On the other, an architect's professional ambition and pecuniary interest are reasons to proclaim a building's heroic qualities and to suppress its less successful elements. The symmetrical purposes of editor and architect can happily conjoin if there's a positive response to the gatekeeper test: Will a building look good on a page, or even better, across what the publishing industry lasciviously describes as a double-page spread? That is, of course, will a photograph of the building look good in print?

This question leads to another: What sort of buildings are photogenic? Even a surface-level architectural trawl would net some camera-friendly types: buildings from the Bauhaus, for instance, and from the recent Iberian masters, contemporary Japanese houses ... All give it up for the camera, in their own way: from the

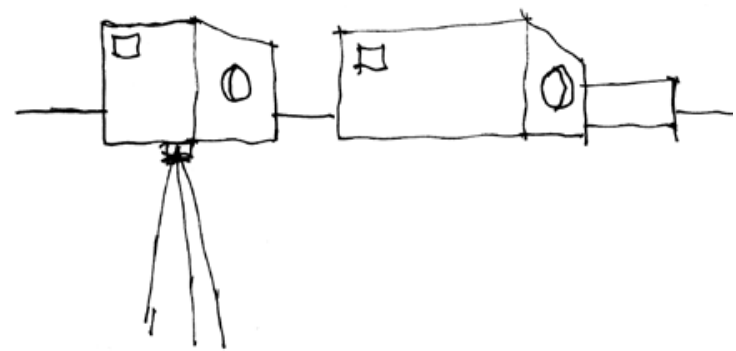


Bauhaus, that austere clarity so suited to monochromatic representation; from Spain, those blindingly white surfaces against a startlingly blue sky; from Japan, those exquisite houses with their model looks. The camera loves these buildings, but, in the hands of a skilled photographer, it can find something to love in just about any building. And if a building is hopelessly unprepossessing, if it has no redeeming features, the photographer can always shoot past it, drawing on the view to distract from the architecture.

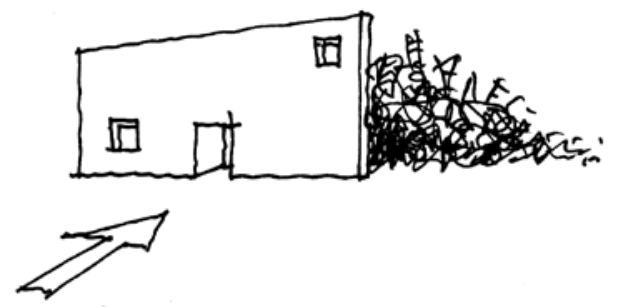

In architectural publishing, commitment to the cause inevitably has some effects. For one thing, editors become converts to formalism - they're not only lookists, they're also shape-ists. It's just that much easier to follow the line, and no type of architecture gives you easier lines to follow than modernism. The movement was a godsend to architectural publishing - you could say they were made for each other. A perfect illustration of the happiness of this marriage is Arts \& Architecture, the Los Angeles-based magazine which, under the influential editorship of John Entenza from the 1940s to the early 1960s, showcased the work of architects such as Richard Neutra, Paul Rudolph and Craig Ellwood.

With its black and white photographs, simple plan drawings, spare layout and sans serif fonts, Arts \& Architecture looked as cool as Chet Baker sounded. Entenza was a conviction editor - he was a founder of the Case Study programme - but you can see why lesser editors like what he liked, even though they don't know what he knew, and why four decades later publishers here colluded in the local renaissance of a formal modernism. They found second-(third-?)time-around modernism congenial because it is so photogenic, even on the inside.

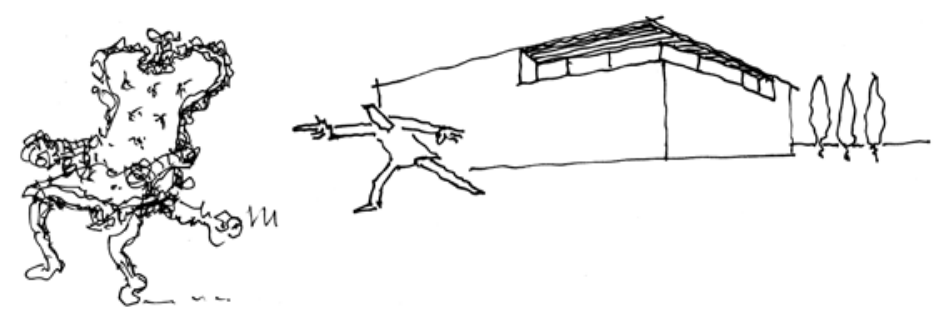

Inside: for the photo-addicted editors of architectural magazines, inside is a problem. Step over the threshold, of a house, especially, and it's a whole other game. There's all that stuff to deal with - possessions, clutter, the vagaries of personal taste; there's the furniture, its vintage, quality and proportions cruelly exposed by the new architecture; and there's the debt, tacit or explicit, owed by the guest to the host.

There are three ways in which editors can respond to the publishing challenge of the interior, which is really the challenge of habitation. The first is avoidance: the photographer takes advantage - rather like a thief in the night - of the window of opportunity between a building's completion and its occupation. Japanese editors and architects are partial to this approach, which focuses attention on the architecture, pure and simple. Another way to deal with the interior condition is 
to wilfully ignore it: hold your nose, don't publish too many photographs of the inside and don't give them much space. This tactic is, usually, not very satisfactory; providing a little photographic information only invites suspicion about why there's not more.

The third tactical response to the interior question is celebration. This is the editorial posture of the nesting magazines, and it requires either the selection of residences whose clients have a furniture fund commensurate with their building budget, or the borrowing of expensive chattels, whose provenance will be duly advertised in the magazine. There's still the question of how to present the people. New Zealand house titles populate their pictures with children lounging, running or jumping into swimming pools, and adults hanging out in the kitchen, dicing vegetables and drinking wine. (Careful with that knife! Who's watching that toddler?)

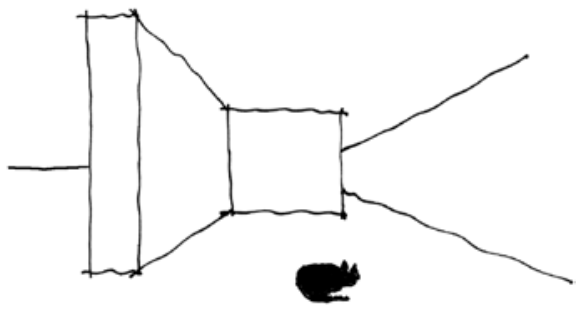

The cheerful and rather gormless materialism favoured by local publishers contrasts with the approaches of some leading international shelter titles. Architectural Digest, for example, plumps for a higher-level vulgarity; World of Interiors mines the deep seams of British aristo-boho idiosyncrasy; and Dwell specialises in vignettes of minimalist urbanity so leached of animation that readers can only think they're witnessing an existential crack-up induced by contemporary architecture.

Editors working in architectural publishing know all about this. For myself, a decade was more than enough time to spend wrestling with the genre's twin threats to the psyche: an exteriority complex, a sense of shallowness caused by the persistent selection of buildings according to the photo-worthiness of their faces; and an interiority complex, a corrosive self-loathing prompted by the obligation to edit people's lives according to the photo-worthiness of their possessions.

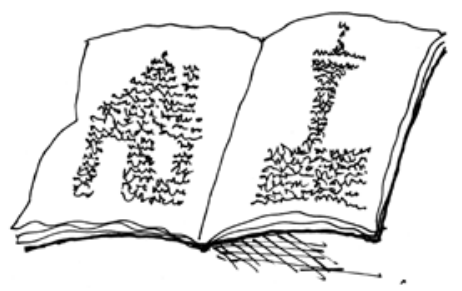

I'm in recovery now, and if I'm ever back in charge of an architecture magazine, I resolve to do things differently. The magazine will comprise only words. Maybe some drawings, but no photographs. Well, perhaps just a few. Very restrained, in classic black and white, like the photos Julius Shulman took. That can't hurt, can it? Full page might be nice - silly to be mean. No people, though; well, maybe one or two, as long as they're not fat or old or badly-dressed. That's okay, isn't it? After all, a magazine has to look good. 